2212 SOFC 発電システムの性能評価技術の開発

\title{
Development of Estimation Method of SOFC System Performance
}

\author{
正吉葉史彦山本融吉川将洋麦倉良啓正渡辺隆夫（電中研）
}

Fumihiko Yoshiba, Tohru Yamamoto, Masahiro Yoshikawa, Yoshihiro Mugikura and Takao Watanabe, Central Research Institute of Electric Power Industry, 2-6-1 Nagasaka Yokosuka Kanagawa, 240-0196

Performances of several kW class SOFC systems are regulated by cell performances and by performances of thermal managements. Cell performances were estimated and the endurance tests were carried out. System performances were regulated by I-V relation of the cells; the heat losses and recirculated heat ratio was evaluated. Based on the results, the analysis method of SOFC system was developed and applied to the practical system.

Key Words : SOFC, System efficiency, Material and heat balance, Module design.

\section{1.緒言}

固体酸化物形燃料電池(SOFC)発電システムにおいて、シ ステム性能を評価することは、開発段階におけるシステム 構成・設計の適正化や、実用段階における熱効率管理法の 適正化に有効となる。

本研究では、SOFC 発電システムの熱効率を容易に明ら かにできるようなシステム内エネルギー収支解析モデルの 作成を基本として、システム性能評価技術を開発する。ま た、異なるコンセプトの基に開発された SOFC 発電システ ムに、電流、スタック電圧、温度等の測定端子を取り付け 実測し、それらの計測データを基に性能評価に必要な様々 な解析を行い、コジェネレーションシステムや発電システ ムとしての電池本体、各種 BOP 機器個別の性能分析を行う。

本報告では、特に長期連続発電試験を実施し、異なるシ ステムの性能推移等に関する分析を行うことにより、本性 能評価手法の有効性に関する検討を行った。

\section{SOFC システム構成の概略}

SOFC システムの性能を決定する要因は大きく分けると 二項目に集約される。一つはSOFC 本体の発電性能であり、 高電流密度の運転条件下でも高いスタック電圧を示すこ とに加え、発電性能の温度依存性が小さいことが要求され る。もう一つは運転状態における熱自立性能である。即ち、 SOFC の作動温度 $\left(600 \sim 800^{\circ} \mathrm{C}\right.$ 程度) を保つこと、燃料の 改質反応時の吸熱反応熱を補うこと、燃料ガスと空気を SOFC の作動温度まで昇温することのため、スタック本体 の発熱と燃焼器での燃焼熱を利用して熱自立することで あるが、この熱自立状態を如何に少ない燃料供給量にて実 現するかがシステムの熱効率に影響する。

SOFC 発電システムの性能評価手法を構築するにあた り、システム構成の大きくことなる二つのシステムを発電 試験に供し、それぞれのシステムについての熱物質収支解 析を行った。供試システムの特徴を表 1 にまとめて示す。

Table.1 Characteristic of operated systems.

\begin{tabular}{|c|c|c|}
\hline & System 1 & System 2 \\
\hline Fuel gas & Natural gas/methane & Methane \\
\hline $\begin{array}{c}\text { Rated power } \\
\text { (DC) }\end{array}$ & $750 \mathrm{~W}$ & $1100 \mathrm{~W}$ \\
\hline $\begin{array}{c}\text { Fuel reforming } \\
\text { process }\end{array}$ & Partial oxidation & Steam reforming \\
\hline $\begin{array}{l}\text { Module cooling } \\
\text { medium }\end{array}$ & Air & --- \\
\hline
\end{tabular}

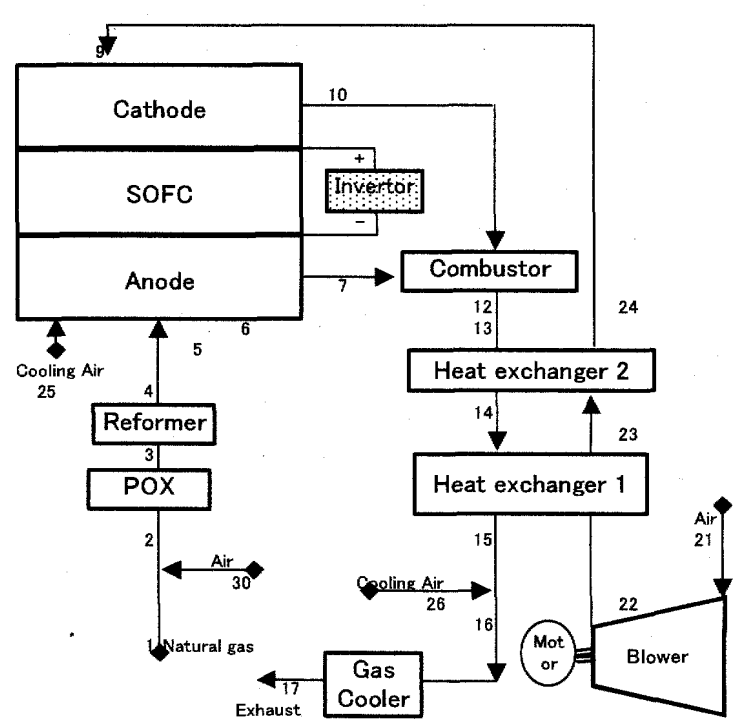

Fig. 1. Schematic design of system 1.

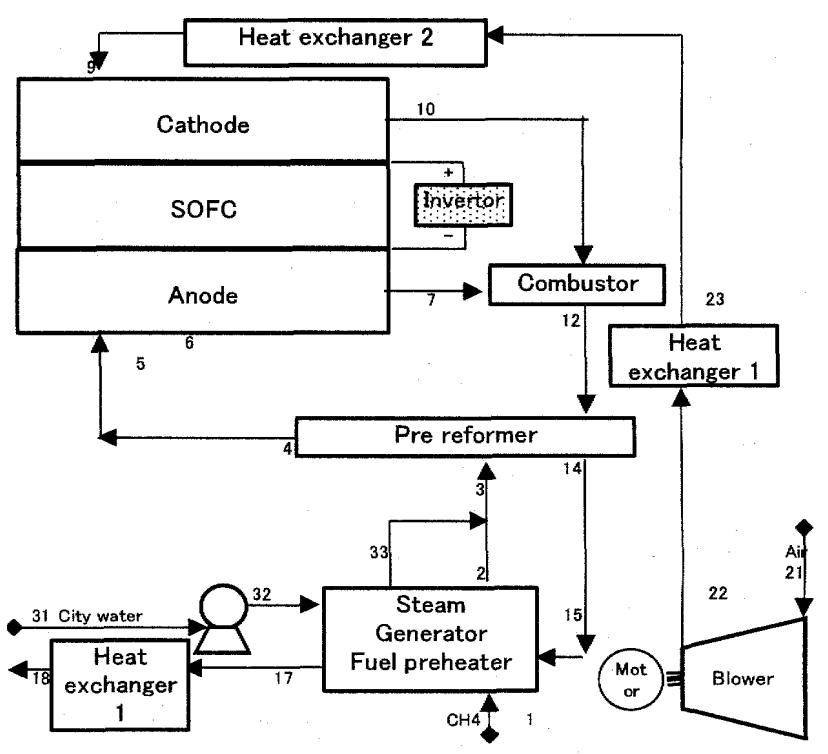

Fig.2. Schematic design of system 2. 
図 1 及び図 2 に発電試験に供した 2 つのシステムフロ 一図を示す。システム構成の大きな差異は、燃料改質方式 である。即ち、システム 1 が燃料の一部を燃焼させること により、改質熱源及び改質用水蒸気を確保するのに対し、 システム 2 では、システムからの排気熱を利用して改質用 水蒸気を生成している。従ってシステム 2 における改質用 熱源は、SOFC からの放散熱もしくは SOFC 排気ガスの燃 焼熱により供給されることとなる。

\section{3.システム発電性能分析結果}

システムの連続発電試験にあたり、システム内の主要発 電機器であるSOFCスタックと同一仕様の単セル試験を別 途実施した。単セル試験では、スタックの運転条件とは異 なり、任意のガス条件や運転温度条件を設定可能である。 当所では、単セルの運転ガス条件之運転温度条件に対し、 電池の電流－電圧の特性を表すことの可能な、性能表示式 を開発している。システムの設計から運転及び長期発電を 行うにあたり、性能表示式を用い、システム内における電 池性能を分析すれば、システム効率の最適化や長期運転時 の熱効率改善に有効となる。

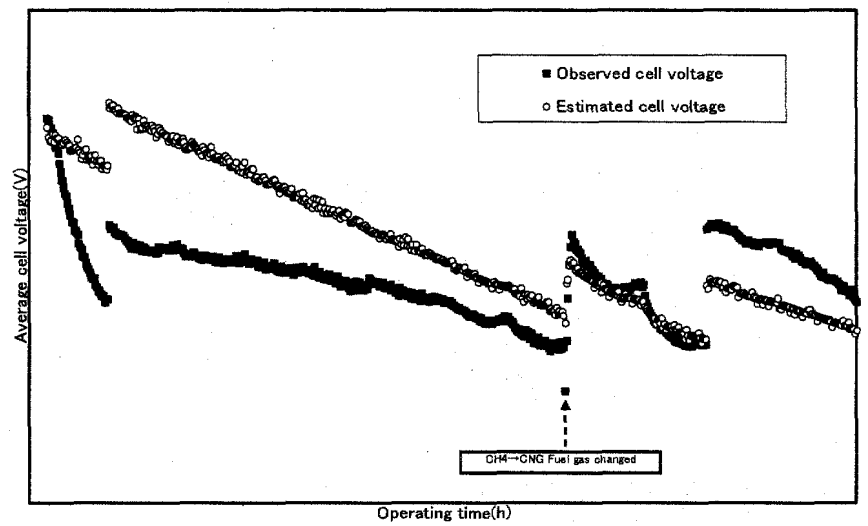

Fig.3 Observed and estimated cell performance of the system 1.

図 3 にシステム 1 の連続発電試験における平均セル電 圧の経時変化実測值を示す。同図には、システム 1 のセル における性能表示式をシステム運転状態に適用し、システ 厶運転状態にて期待されるセル性能を合わせて示した。発 電初期では、単セルから予測される性能がシステムにおい ても十分に発揮されていることが分かる。また、連続発電 の時間経過に伴い、実測セル電圧が低下しているものの、 発電試験の後期では、実測セル電圧の方が性能表示式によ り予測される電圧を上回る結果を得た。性能表示式の運転 温度別の長期変化等を捉えることにより、よりシステム運 転条件に近い性能分析が可能となっていくものと考えら れる。

図 4 及び図 5 にはシステム 2 における連続発電試験前 後のシステム内エネルギーフロー状態の変化を比較して 示す。発電性能の低下主要因はセル性能の低下であるが、 放散熱の増加や熱循環割合の減少等も伴っていることが 分かる。これらの電池性能と熱自立性能の両者が、長期発 電条件においても安定して推移するようなシステム設計 を行うことが重要であり、電池の性能表示式とエネルギー フロー状態の分析を結びつけによる性能評価手法がシス テム性能適正化に適用可能であることを明らかとした。

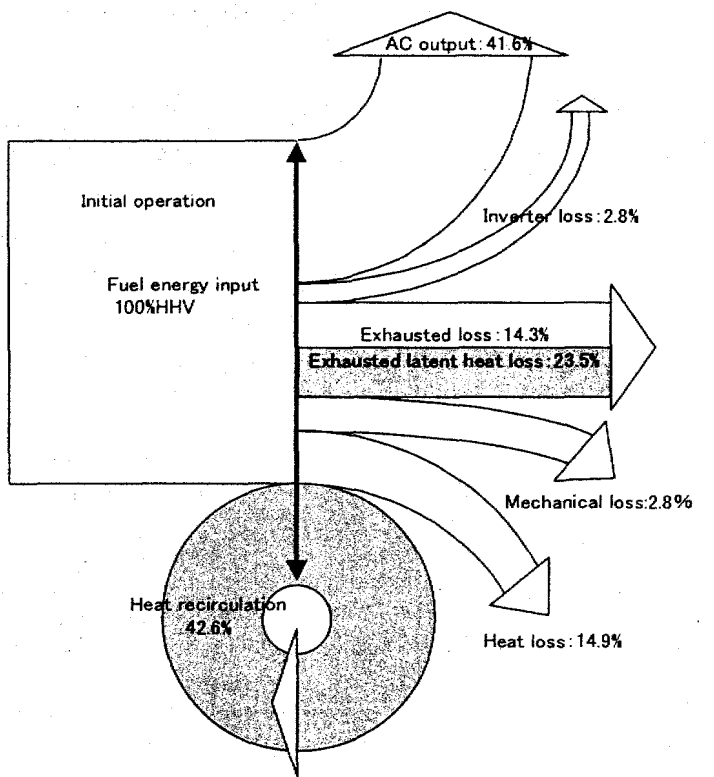

Fig.4 Energy flow of the system 2 (Initial).

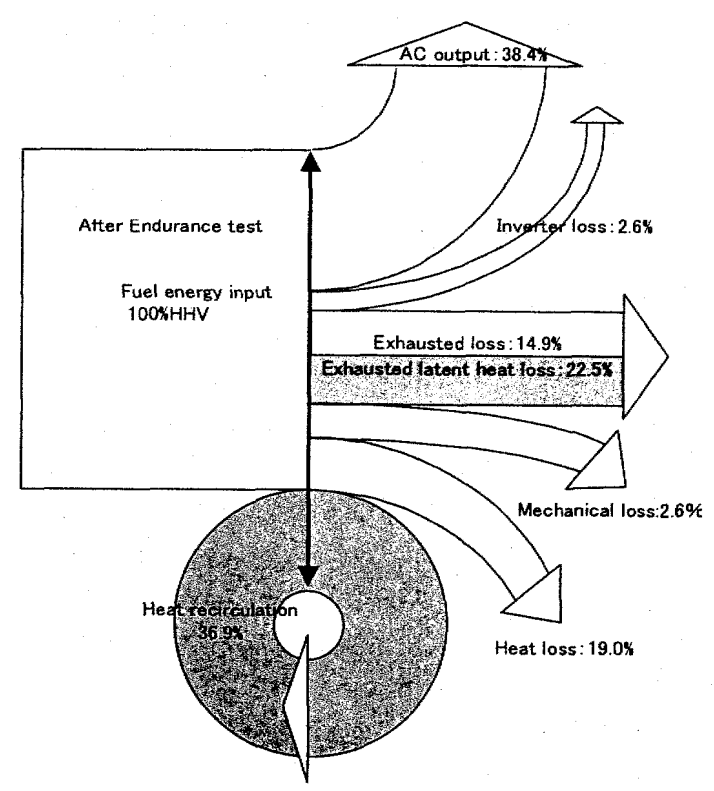

Fig. 5 Energy flow of the system 2 (After Endurance test).

\section{4.結言}

SOFC 発電システムにおける発電性能評価手法の開発と して、システム構成の大きくことなる二つのシステムの連 続発電試験を実施した。また、性能表示式によるセル性能 の定量化と、システム内エネルギーフロー解析との結合に より、長期システム運転条件におけるエネルギーロス状態 を分析可能なツールを開発した。

本研究は、独立行政法人新エネルギー・産業技術総合開 発機構からの委託研究「固体酸化物形燃料電池システム性 能評価技術の開発」にて実施したものであり、関係各位の 謝意を表します。

\section{参考文献}

1)J. Palsson, et. al., CIMAC Congress proceedings, 2004.

2)F. Yoshiba et. al., ECS Transaction, 7 (1) 697-701(2007). 